\title{
Nonarteritic anterior ischemic optic neuropathy following pars plana vitrectomy for macular hole treatment: case report
}

\author{
Neuropatia óptica isquêmica anterior não arterítica pós vitrectomia pars plana para \\ tratamento do buraco macular: relato de caso
}

Leonardo Provetti Cunha ${ }^{1,2}$, Luciana Virgínia Ferreira Costa Cunha ${ }^{2}$, Carolina Ferreira Costa², Mário Luiz Ribeiro Monteiro 3

\begin{abstract}
Herein, we report a case of nonarteritic anterior ischemic optic neuropathy (NAION) following uneventful pars plana vitrectomy for macular hole treatment. A 56-year-old previously healthy woman presented with a full-thickness macular hole in right eye (OD) and small cup-to-disc ratios in both eyes. Five days after surgery, she noticed sudden painless loss of vision in OD and was found to have an afferent pupillary defect and intraocular pressure of $29 \mathrm{mmHg}$. Fundus examination showed right optic disc edema and the resolution of a macular hole with an inferior altitudinal visual field defect. Erythrocyte sedimentation rate, C-reactive protein levels, and general physical examination findings were normal. She was treated with hypotensive eyedrops and oral prednisone, resulting in mild visual improvement and a pale optic disc. A combination of face-down position and increased intraocular pressure due to a small optic disc cup were considered as potential mechanisms underlying NAION in the present case. Vitreoretinal surgeons should be aware of NAION as a potentially serious complication and be able to recognize associated risk factors and clinical findings.
\end{abstract}

Keywords: Optic neuropathy, ischemic/diagnosis; Papilledema; Retinal perforations/therapy; Vitrectomy; Visual fields

\begin{abstract}
RESUMO
Nosso objetivo é descrever a ocorrência de neuropatia óptica isquêmica anterior não-arterítica (NOIA-NA) após vitrectomia posterior para tratamento do buraco macular. Uma mulher de 56 anos de idade previamente hígida apresentou buraco macular de espessura total no olho direito (OD) e uma relação escavação disco pequena em ambos os olhos. No quinto dia de pós-operatório ela notou uma perda visual súbita e indolor $O D$ associado a presença de um defeito pupilar aferente relativo e pressäo intraocular de $29 \mathrm{mmHg}$ neste mesmo olho. A avaliação do fundo de olho revelou a presença de edema de disco óptico e buraco macular fechado OD associado a presença de defeito de campo visual altitudinal inferior. A velocidade de hemossedimentação e a dosagem da proteína C reativa foram normais, assim como o exame físico geral. A paciente foi tratada com colírios hipotensores e prednisona oral e evoluiu com discreta melhora visual e palidez de disco óptico. Acreditamos que a combinação de posição de cabeça virada para baixo associado a um aumento da pressão intraocular em um paciente com relação escavação disco pequena são os possiveis mecanismos para a ocorrência de NOIA-NA neste presente caso. Os cirurgiöes de retina e vítreo devem estar atentos a esta possível grave complicação e reconhecer os seus fatores de risco relacionados assim como sua apresentação clinica.
\end{abstract}

Descritores: Neuropatia óptica isquêmica/diagnóstico; Papiledema; Perfurações retinianas/terapia; Vitrectomia; Campos visuais

\section{INTRODUCTION}

Pars plana vitrectomy (PPV) with perimacular traction removal and facedown intraocular gas tamponade have demonstrated utility in treating idiopathic full-thickness macular holes (FTMH). Despite great advances in surgical technique over the last few years with the achievement of good anatomical and functional outcomes, FTMH surgical treatment remains associated with a number of ocular complications, including retinal detachment, retinal tears, enlargement of the hole, macular phototoxicity, postoperative intraocular pressure (IOP) elevation, and cataracts ${ }^{(1,2)}$. Furthermore, visual field (VF) defects associated with peripapillary retinal nerve fiber layer (RNFL) thickness reduction, optic neuropathy, and optic disc pallor may occur after otherwise uncomplicated surgery for macular hole treatment. Although various underlying mechanisms, including optic nerve and retinal ischemia, have been proposed, the exact cause remains unclear ${ }^{(3-5)}$. Visual loss from optic neuropathy following uncomplicated PPV for idiopathic FTMH treatment is a rare and potentially

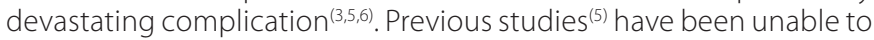
fully elucidate the mechanisms underlying visual loss, with only one study documenting the occurrence of nonarteritic anterior ischemic optic neuropathy (NAION) following uncomplicated PPV. The exact incidence of NAION, however, may be underestimated as optic disc evaluations are usually impaired by the presence of intraocular gas during the early postoperative period.

Here, we aimed to report the incidence of NAION following uneventful PPV for idiopathic FTMH treatment and discuss the potential mechanisms underlying this serious postoperative complication.

\section{CASE REPORT}

A 56-year-old previously healthy woman reported a 6-month history of progressive visual decline in her right eye (OD). Her past medical history was unremarkable, with no history of stroke, myocardial infarction, dyslipidemia, sleep apnea syndrome, or smoking. Best-corrected visual acuity (VA) was 20/200 in OD, 20/20 in the left eye (OS). Slit lamp examination was normal; the patient was phakic, and the anterior chamber angle was wide open in both eyes on gonioscopy. IOP was $18 \mathrm{mmHg}$ in OD and $19 \mathrm{mmHg}$ in OS. Fundus
Submitted for publication: August 24, 2015

Accepted for publication: February 12, 2016

Universidade Federal de Juiz de Fora, Juiz de Fora, MG, Brazil.

2 Hospital de Olhos Juiz de Fora, Juiz de Fora, MG, Brazil.

${ }^{3}$ Universidade de São Paulo, São Paulo, SP, Brazil.
Funding: No specific financial support was available for this study.

Disclosure of potential conflicts of interest: None of the authors have any potential conflict of interest to disclose.

Corresponding author: Leonardo Provetti Cunha. Av. Barão Rio Branco, 4.051 - Juiz de Fora, MG - 36021-630 - Brazil - E-mail: leonardo_provetti@yahoo.com.br 
examination revealed normal optic nerves with a cup-to-disc ratio of 0.2 , partial posterior vitreous detachment, and a macular hole in OD (Figure 1 A), and was normal in OS. Optical coherence tomography (OCT) showed a full-thickness macular hole with overlying operculum (Figure 1 B). Under retrobulbar anesthesia, she underwent an uneventful 25-gauge posterior PPV with posterior hyaloid separation followed by internal limiting membrane (ILM) staining with brilliant blue G (Ophthalmos ${ }^{\text {TM }}$, Brazil) for 30 s. Subsequently, intraocular forceps were used to circumferentially peel ILM around the macular hole. A few self-limited, small, superficial, pre-retinal hemorrhages occurred in the peeled macular area. Then, fluid-air exchange and air-gas exchange with $20 \%$ SF $_{6}$ were performed. No hyper- or hypotensive events were observed intraoperatively. The patient was instructed to maintain a face-down position for 5 days postoperatively.

The initial postoperative VA was 20/400, with an IOP of $10 \mathrm{mmHg}$ in the operative eye. On the fifth postoperative day, the patient noticed sudden painless vision loss, with the VA reduced to finger counting at 1 meter in OD. On examination, she had a right relative afferent pupillary defect with an IOP of $29 \mathrm{mmHg}$ in OD. Her right optic nerve was edematous (Figure 2 A). OCT imaging of the macular area revealed macular hole closure (Figure 2 B). Automated perimetry was obtained on the $14^{\text {th }}$ post-operative day and demonstrated a diffuse reduction of sensitivity with an inferior altitudinal defect (Figure 3 ). The erythrocyte sedimentation rate (ESR) was $20 \mathrm{~mm} / \mathrm{h}$, C-reactive protein (CRP) was $<0.3 \mathrm{mg} / \mathrm{l}$, and the patient denied any symptoms suggestive of giant cell arteritis (GCA). A fixed combination of timolol maleate $0.5 \%$ and brimonidine tartrate $0.2 \%$ (Combigan ${ }^{\circledR}$ ) twice daily for OD was initiated in combination with $80 \mathrm{mg}$ of prednisone orally for 7 days with subsequent dose tapering. Three months later, the best-corrected visual acuity was 20/160-10 D. The right optic nerve was pale, and the macular hole remained closed (Figure 4).

\section{DISCUSSION}

NAION is the most common optic neuropathy in patients $>50$ years old; it is thought to be a multifactorial disease involving an ischemic process resulting from microvascular occlusion or hypoperfusion of the blood supply to the optic nerve head, resulting in sudden visual loss associated with pale optic disc edema.

Taban et al. described two cases of NAION after uncomplicated vitrectomy for macular hole and epiretinal membrane ${ }^{(6)}$ : A 65-year-old phakic hypertensive and diabetic woman and a 94-year-old aphakic hypertensive man. Both patients developed sudden visual loss and optic disc edema in the operated eye approximately 1 month after vitrectomy, with NAION subsequently diagnosed. The present case differs because the patient was younger and had no systemic risk factors such as hypertension or diabetes mellitus. Furthermore, she presented with visual loss soon after surgery, which reinforces the role of PPV in the development of NAION.

More recently, Bansal et al. retrospectively reviewed 7 patients who underwent PPV for primary regmatogenous retinal detachment with subsequent development of optic neuropathy, with comparison to 42 age- and gender-matched patients undergoing similar surgery. Despite the apparent lack of structural findings early in the postoperative period, all 7 patients eventually developed optic nerve pallor, a relative afferent pupillary defect, and VF defects. The authors further performed a review of 37 previously reported eyes with VF defect after PPV and found that none had documented disc edema despite the authors positing ischemia as a potential cause. While the authors indicated that the presence of an intraocular gas bubble precluded a detailed assessment of the optic nerve head during the postoperative period, they postulated that post-vitrectomy optic neuropathies are more consistent with posterior ischemic optic neuropathy, similar to those seen after spine surgery ${ }^{(5)}$. The present case in addition to
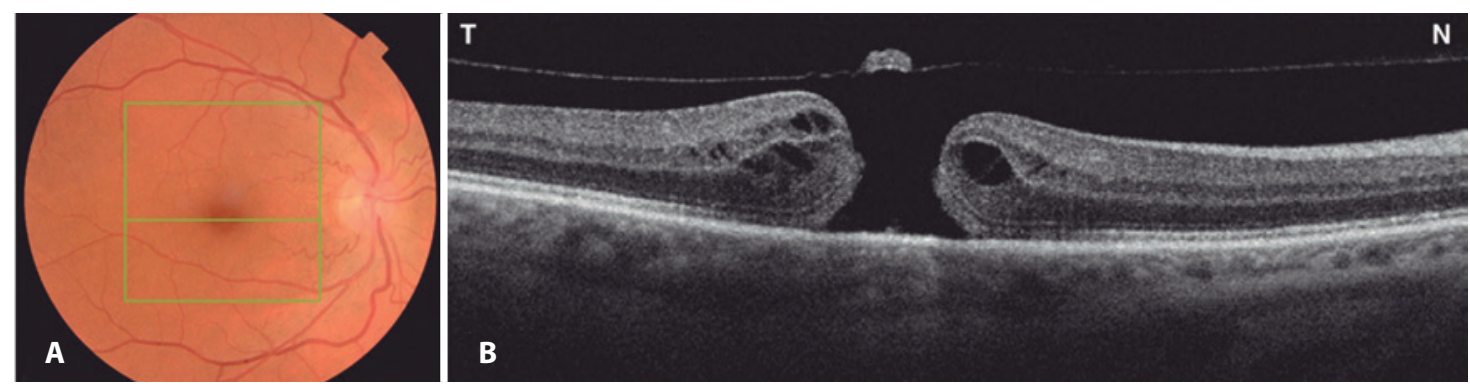

Figure 1. A) Preoperative fundus retinography demonstrating normal optic nerves with a small cup-to-disc ratio and macular hole affecting the right eye. The green square represents the area of the macular hole $(6 \times 6 \mathrm{~mm})$ on optical coherence tomography (OCT). The central green horizontal line represents the OCT scan through the center of the fovea. B) OCT (horizontal scan) of the same eye demonstrating a full-thickness macular hole with overlying operculum.
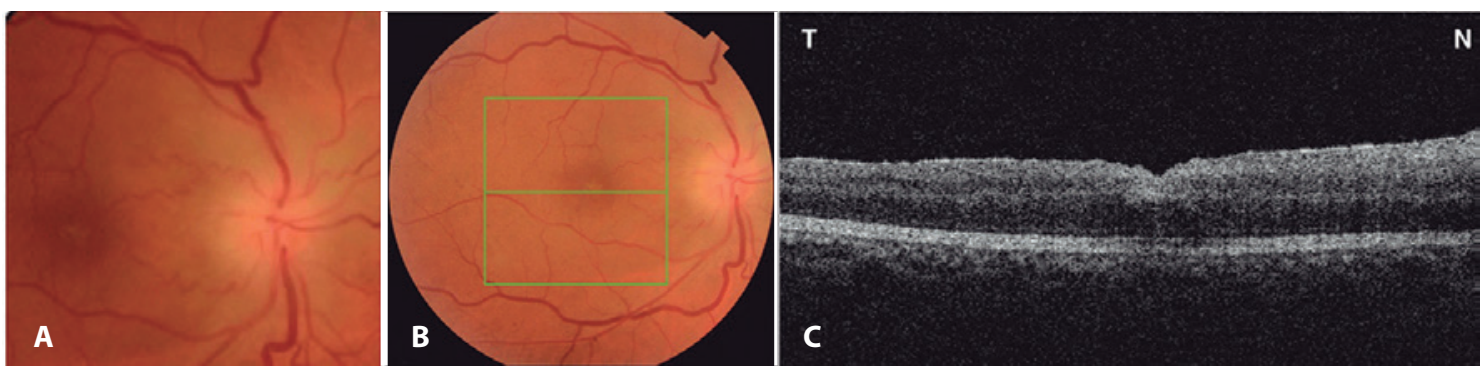

Figure 2. A) Fundus retinography demonstrating optic disc edema affecting the right eye 7 days after surgery. B) Fundus retinography of same eye. C) Optical coherence tomography (horizontal scan) demonstrating complete closure of the macular hole. 

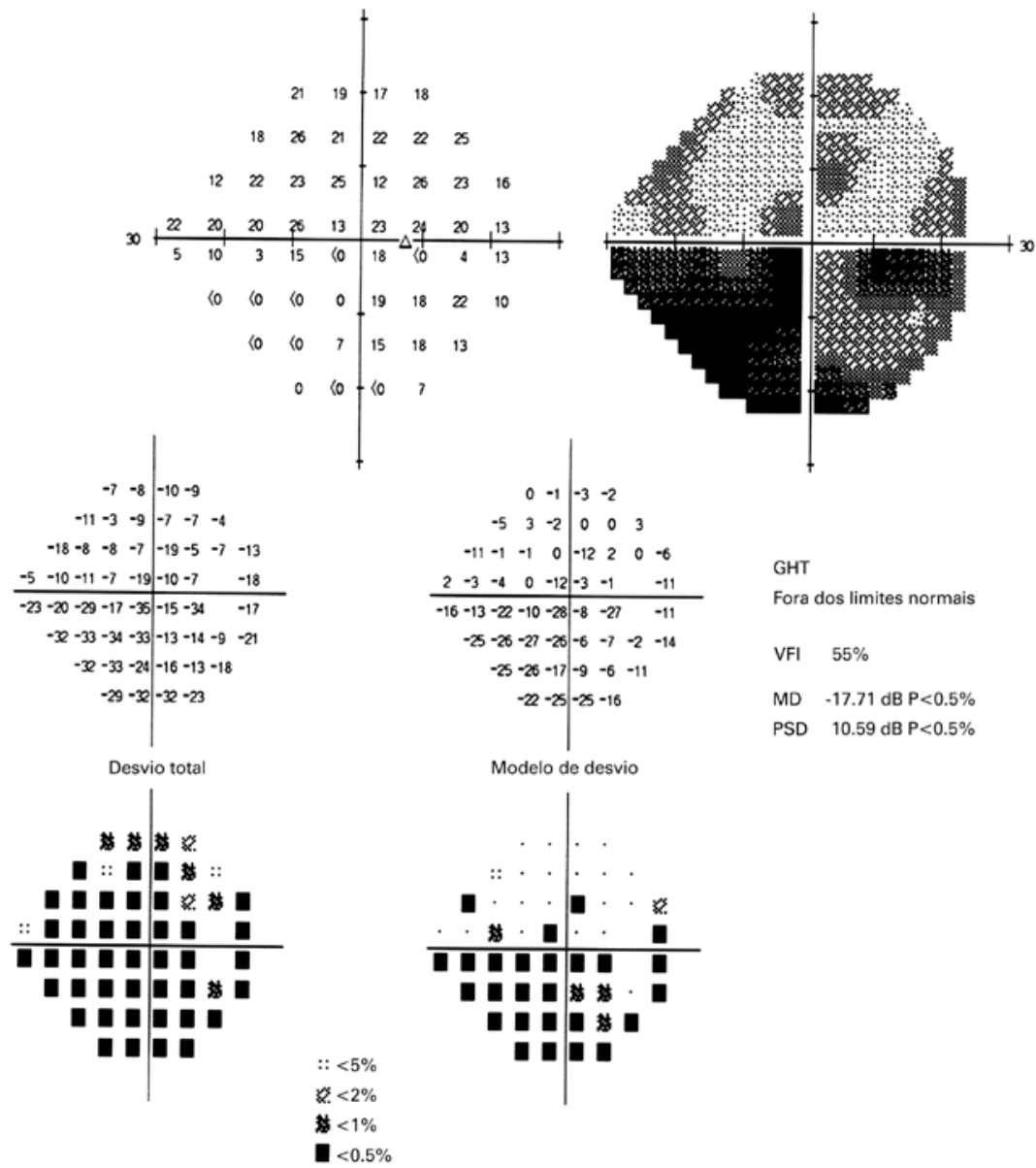

GT

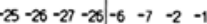

$-25-26-17-9-6-11$

$-22-25-25-16$

dos limites normais

VFI $55 \%$

MD $\quad-17.71 \mathrm{~dB} P<0.5 \%$

PSD $10.59 \mathrm{~dB} P<0.5 \%$

Modelo de desvio
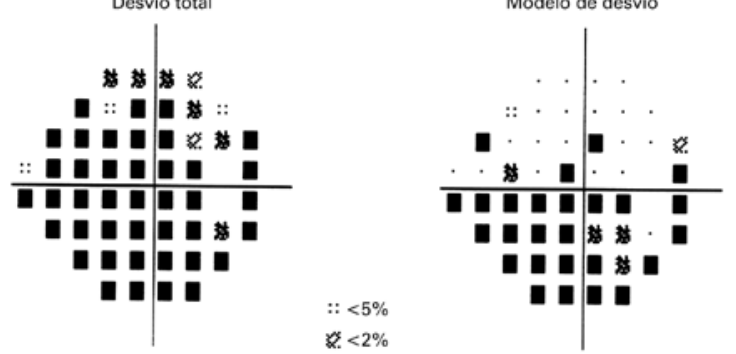

Figure 3. Automated Humphrey visual field (24-2) of the right eye, 14 days after the procedure, revealing diffuse depression and an inferior altitudinal defect that was more pronounced in the inferior nasal quadrant.
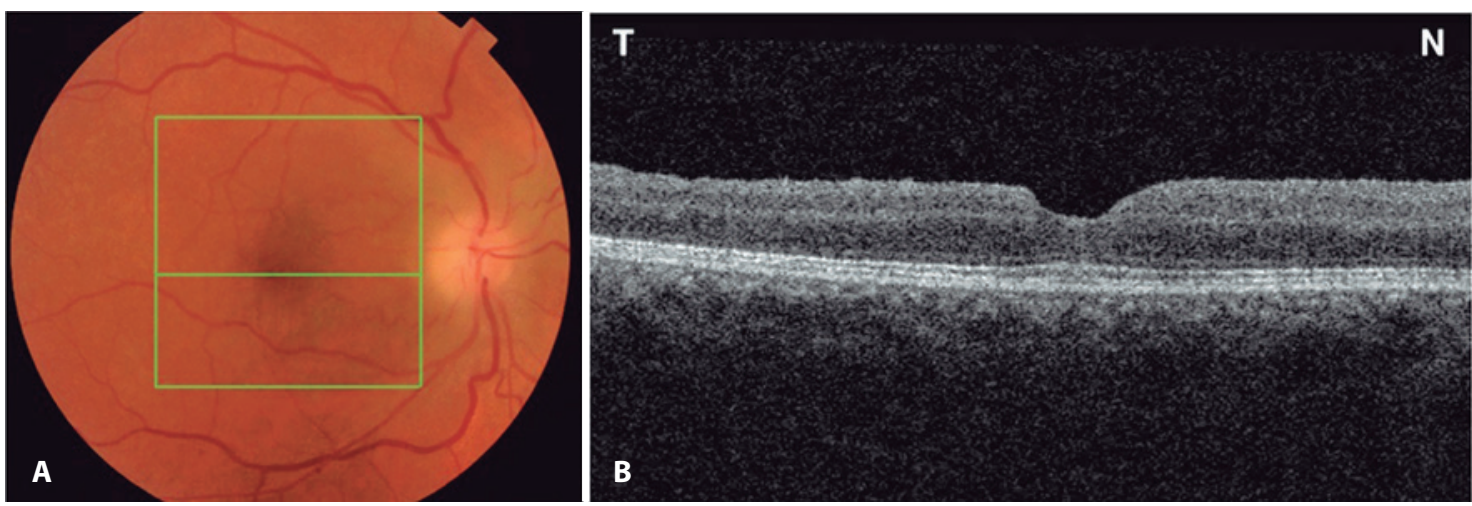

Figure 4. A) Fundus retinography demonstrating optic disc pallor in the right eye 3 months after surgery. B) Optical coherence tomography (horizontal scan) of the same eye demonstrating complete closure of the macular hole with foveal depression recovery.

those described by Bansal et al.(5) indicate that optic neuropathy with optic disc edema (anterior ischemic optic neuropathy) may, in fact, occur. Furthermore, we agree with Taban et al. ${ }^{(6)}$ that visibility is difficult early during the post-operative period due to the presence of an intraocular gas bubble. Accordingly, the occurrence of optic disc edema may be an under-reported phenomenon.
While the exact mechanisms underlying the development of optic neuropathy after PPV have yet to be fully elucidated, a combination of factors may have contributed to the occurrence of NAION after posterior vitrectomy in the present case. We believe the combination of face-down position and increased IOP during the postoperative period of macular hole surgery may play an important role 
in the development of $\mathrm{NAION}^{(7)}$. One possible explanation is that the blood flow to the optic nerve head, which is dependent on perfusion pressure, may have been impaired. Ocular perfusion pressure is the difference between mean arterial blood pressure and IOP or venous pressure. Since both IOP and venous pressure are increased in the prone position, the combination of these two events may precipitate ischemia of the anterior portion of the optic nerve, resulting in NAION. Although we documented only a moderate increase in IOP in the present case, IOP may have reached a much higher level before examination and thereby contributed to the development of $\mathrm{NAION}^{(8)}$. The association between face-down position and increased IOP is well described, notably in low-light conditions, and can be used in clinical practice as a provocative test for angle-closure glaucoma ${ }^{(7)}$. The exact mechanism underlying IOP elevation is not completely understood, but it may be related to forward movement of the lens in the prone position, particularly when associated with mydriasis, possibly leading to anterior chamber angle closure and impaired aqueous humor out-flow. Therefore, we believe a combination of such factors may have contributed to IOP elevation in the present case.

Other factors may contribute to the occurrence of NAION after vitreoretinal surgery, e.g., posterior vitreous detachment, indicating that direct mechanical trauma to the optic disc during separation of the posterior hyaloid may lead to damage to the retinal arterioles, nerve fiber layer, or retina ${ }^{(6,9)}$. Parsa and Hoyt posited that the vitreous adhesion over the optic disc and peripapillary retina may be particularly strong over the cupless disc, with stretching and elongation during posterior vitreous detachment breaking the cytoskeleton in older and less distensible axons, leading to axoplasmic accumulation and axonal atrophy in the prelaminar sites of separation ${ }^{(9)}$. In the present case, the posterior hyaloid was adhered to the peripapillary area, indicating the traction induced during aspiration of the posterior cortical vitreous may have resulted in axonal damage. However, this is less likely as visual loss was present on the first and not the fifth postoperative day in the present case.

Another possible explanation for NAION after macular hole repair is indirect mechanical trauma induced by high infusion pressure during air-fluid exchange. However, in our patient, a system that constantly monitors air pressure infusion was used (The Constellation ${ }^{\circledR}$ Vision System, Alcon Laboratories) and the target pressure was set at $30 \mathrm{mmHg}$, which is the standard for the majority of vitrectomy surgeries, making this hypothesis less feasible. Indeed, Hirata et al. demonstrated that reduced air pressure infusion to $30 \mathrm{mmHg}$ de- creased the incidence of VF defects after macular hole surgery from $24 \%$ to $4 \%(10)$.

Bansal et al. posited that reduced ocular perfusion due to intraoperative systemic hypotension may be a risk factor for the development of optic neuropathy after PPV ${ }^{(5)}$. That explanation, however, is also difficult to reconcile with the findings of the present case as visual loss clearly developed within 5 days of surgery. A final possibility is that the occurrence of NAION in the present case may have been a coincidental event unrelated to surgery asNAION is the most common optic neuropathy in patients in the sixth decade of life. However, we consider this possibility s very unlikely.

In conclusion, we believe the combination of face-down positioning and increased IOP with other risk factors, such as a small optic disc cup, may have predisposed the present case to NAION after apparently uneventful posterior vitrectomy for macular hole treatment. Vitreoretinal surgeons should be aware of this potentially serious complication and recognize its risk factors and clinical findings.

\section{REFERENCES}

1. Jackson TL, Donachie PH, Sallam A, Sparrow JM, Johnston RL. United Kingdom National Ophthalmology Database study of vitreoretinal surgery: report 3, retinal detachment. Ophthalmology. 2014;121(3):643-8.

2. Gupta OP, Weichel ED, Regillo CD, Fineman MS, Kaiser RS, Ho AC, et al. Postoperative complications associated with 25-gauge pars plana vitrectomy. Ophthalmic Surg Lasers Imaging. 2007;38(4):270-5.

3. Ezra E, Arden GB, Riordan-Eva P, Aylward GW, Gregor ZJ. Visual field loss following vitrectomy for stage 2 and 3 macular holes. Br J Ophthalmol. 1996;80(6):519-25.

4. Williams JM, Jacobson Sr DM. Visual field loss after vitreous surgery. Arch Ophthalmol. 1997;115(3):434-5.

5. Bansal AS, Hsu J, Garg SJ, Sivalingam A, Vander JF, Moster M, et al. Optic neuropathy after vitrectomy for retinal detachment: clinical features and analysis of risk factors. Ophthalmology. 2012;119(11):2364-70.

6. Taban M, Lewis $H$, Lee MS. Nonarteritic anterior ischemic optic neuropathy and 'visual field defects' following vitrectomy: could they be related? Graefes Arch Clin Exp Ophthalmol. 2007;245(4):600-5.

7. Hyams SW, Friedman Z, Neumann E. Elevated intraocular pressure in the prone position. A new provocative test for angle-closure glaucoma. Am J Ophthalmol. 1968;66(4): 661-72.

8. Torricelli A, Reis AS, Abucham JZ, Suzuki R, Malta RF, Monteiro ML. Bilateral nonarteritic anterior ischemic neuropathy following acute angle-closure glaucoma in a patient with iridoschisis: case report. Arq Bras Oftalmol. 2011;74(1):61-3.

9. Parsa CF, Hoyt WF. Nonarteritic anterior ischemic optic neuropathy (NAION): a misnomer. Rearranging pieces of a puzzle to reveal a nonischemic papillopathy caused by vitreous separation. Ophthalmology. 2015;122(3):439-42.

10. Hirata A, Yonemura N, Hasumura T, Murata Y, Negi A. Effect of infusion air pressure on visual field defects after macular hole surgery. Am J Ophthalmol. 2000;130(5):611-6.

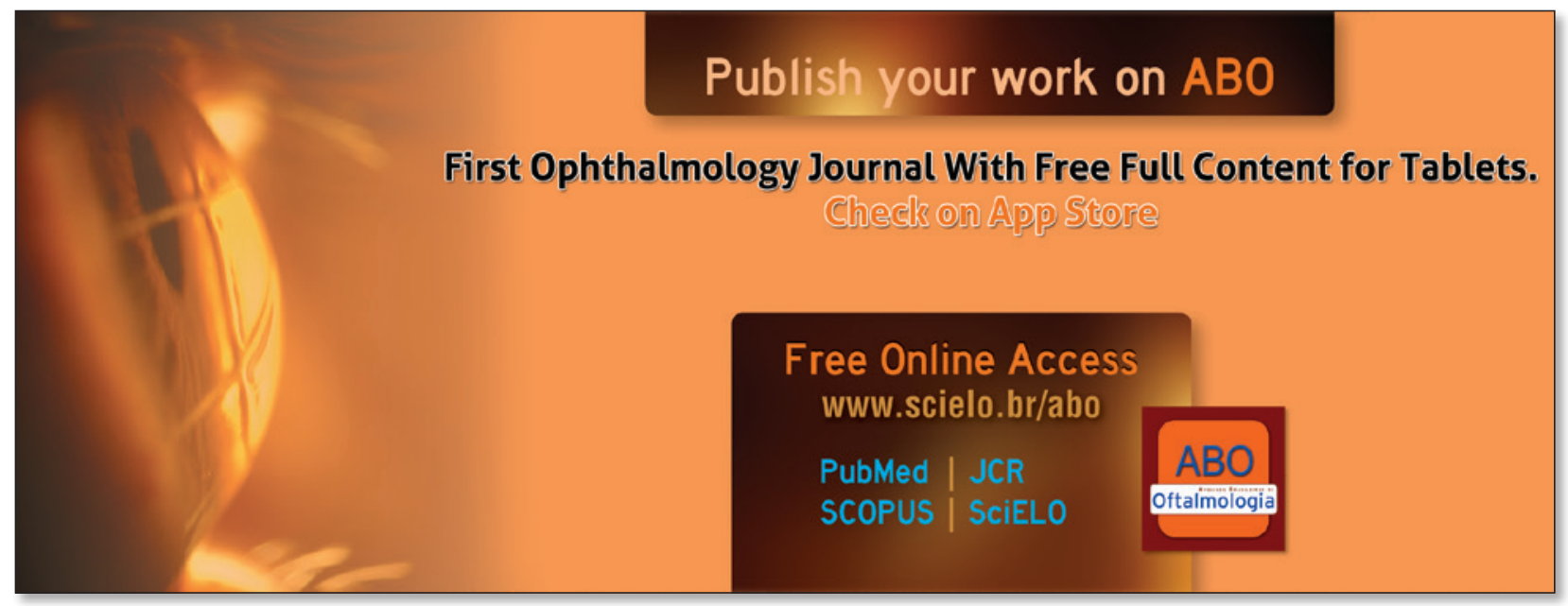

